\title{
PENGEMBANGAN PODCAST APLIKASI PANDUAN AKADEMIK (APIK) JURUSAN TEKNIK INFORMATIKA ITN MALANG BERBASIS ANDROID
}

\author{
Edwin Martha Kusuma, Karina Auliasari, Mira Orisa \\ Program Studi Teknik Informatika S1, Fakultas Teknologi Industri \\ Institut Teknologi Nasional Malang, Jalan Raya Karanglo km 2 Malang, Indonesia \\ Edwinmk666@gmail.com
}

\begin{abstract}
ABSTRAK
Pemanfaatan sebuah teknologi informasi (IT) di lingkungan perguruan tinggi mempunyai peran yang besar, memiliki fungsi awal sebagai alat bantu dalam menyelesaikan persoalan dalam segala bidang, Salah satu penerapan teknologi informasi yang banyak dimanfaatkan sekarang adalah teknologi multimedia interaktif berbasis animasi. Di lingkungan kampus, mahasiswa yang baru memasuki jenjang perguruan tinggi setiap mahasiswa harus bisa memahami panduan akademik di kampus yang dapat dijadikan sebagai acuan teknis tata cara mengikuti perkuliahan dan kegiatan kampus. Maka sehubungan dengan hal ini setiap mahasiswa baru perlu adanya pengenalan panduan akademik yang lebih menarik, atraktif dan efektif bagi mahasiswa baru supaya panduan akademik dapat cepat dipahami dan dimengerti oleh mahasiswa baru Teknik Informatika ITN Malang. Aplikasi ini dapat memberi manfaat dan pengetahuan bagi mahasiswa di Teknik Informatika ITN Malang yang baru mengenal lingkungan kampus.
\end{abstract}

Kata kunci : perguruan tinggi, panduan akademik, multimedia.

\section{PENDAHULUAN}

\subsection{Latar Belakang}

Pemanfaatan sebuah teknologi informasi (IT) di lingkungan perguruan tinggi mempunyai peran yang besar, memiliki fungsi awal sebagai alat bantu dalam menyelesaikan persoalan dalam segala bidang, sekarang juga bisa berfungsi sebagai media penyampaian informasi. Hal ini ditandai dengan banyak penelitian yang diterapkan dalam media informasi. Seperti penelitian tentang pembuatan aplikasi akademik online berbasis mobile android pada universitas tama jagakarsa, yang dapat menyediakan layanan akademik berbasis Android untuk membantu pengguna baik mahasiswa, dosen maupun staff-staff untuk mengetahui informasi akademik yang terbaru. Melalui perangkat Android yang telah terhubung dengan jaringan internet, maka pengguna langsung dapat login kedalam akademik online yang akan menampilkan data informasi akademik berupa biodata Mahasiswa, KRS, Jadwal, KHS, Pengumuman yang terdapat pada aplikasi melalui menu yang disediakan[8].

Setelah itu penelitian tentang buku Panduan akademik digital berbasis android pada stimik akikom yokyakarta, yang memanfaatkan teknologi mobile dan web service sehingga dapat mempermudah user dalam mengakses informasi akademik. Selain itu, aplikasi ini juga mempermudah admin ketika akan melakukan olah data dengan adanya web service. [6].

Di lingkungan kampus, mahasiswa yang baru memasuki jenjang perguruan tinggi, harus bisa memahami panduan akademik di kampus yang dapat dijadikan sebagai acuan teknis tata cara prosedur akademik seperti pembayaran spp, pemrograman krs,dan pemrograman batal tambah. mahasiswa yang telah menjalani kuliah juga belum tentu mengetahui tentang tata cara prosedur akademik seperti prosedur pengajuan cuti, pengajuan pkn, dan pengajuan skripsi. Maka sehubungan dengan hal ini setiap mahasiswa baru perlu adanya pengenalan panduan akademik yang lebih menarik, atraktif dan efektif bagi mahasiswa baru supaya panduan akademik dapat cepat dipahami dan dimengerti oleh mahasiswa baru Teknik Informatika ITN Malang.

Karena di ITN masih beluma ada aplikasi yang dapat membantu mahasiswa dalam hal tersbut, penulis memutuskan untuk membuat apikasi "APIK". Aplikasi ini dapat memberi manfaat dan pengetahuan bagi mahasiswa di Teknik Informatika ITN Malang yang baru mengenal lingkungan kampus. Sehingga dengan adanya aplikasi ini diharapkan dapat dijadikan juga sebagai media panduan informasi digital dan media pembelajaran interaktif dan menarik bagi mahasiswa yang baru menjalani kuliah di Teknik Informatika ITN Malang.

\subsection{Rumusan Masalah}

Dari latar belakang tersebut maka dicari suatu pemecah masalah yaitu :

1. Bagaimana cara merancang dan mengimplementasikan video podcast pada aplikasi panduan akademik berbasis android ?

2. Bagaimana cara membuat suatu aplikasi yang dapat lebih efektif dalam menyampaikan informasi panduan akademik Teknik Informatika ITN malang? 


\section{TINJAUAN PUSTAKA}

\subsection{Penelitian Terdahulu}

Mahasiswa saat ini adalah mahasiswa yang sangat antusias dengan teknologi mobile, dan beberapa teknologi ini menawarkan peluang yang signifikan untuk memperluas waktu, tempat dan cara belajar. Salah satunya adalah podcasting [9].

Belakangan, podcast juga mengacu pada materi dalam bentuk video. Sehingga pengertian podcast dapat mengacu pada podcast audio atau podcast video. Apple sendiri membuat batasan podcast sebagai siaran audio dan video yang tersedia di internet untuk diputarkan pada perangkat portable atau computer. Singkat cerita, istilah podcast diartikan sebagai materi audio atau video yang tersedia di internet yang dapat secara otomatis dipindahkan ke komputer atau media [4].

Jadi, podcast dapat memungkinkan siswa mendengarkan materi yang terkait dengan mata kuliah saat melakukan kegiatan lain. Di masa lalu seorang mungkin menggunakan waktu tersebut untuk membuat catatan kuliah mereka, atau membaca referensi, tetapi penggunaan pemutar media digital memberikan kemudahan untuk menyampaikan materi tersebut dalam bentuk podcast [9].

Penelitian di universitas jurusan bisnis dan manajemen di London, Inggris yang melibatkan 401 mahasiswa, menunjukkan bahwa siswa menghargai fleksibilitas yang ditawarkan oleh podcast dalam mendengarkan materi di semua tempat. Seperempat dari mereka mendengarkan saat bepergian. Ini menunjukkan bahwa podcasting bisa melakukan kegiatan dan belajar secara bersamaan [3].

\subsection{Landasan Teori}

\subsubsection{Podcast}

Podcast adalah jenis media digital yang terdiri dari serangkaian episodik audio atau video. podcast audio telah berkembang sejak tahun 2005, saat Apple menambahkan materi podcast pada iTunes dengan tema-tema terbatas. Seiring waktu, materi podcast semakin berkembang dan beragam. Kemasannya dapat berupa sandiwara/drama, dialog/talkshow, monolog dan feature/dokumenter. Ren-tang topiknya sangat luas, mulai dari sejarah, ilmu pengetahuan, politik, ekonomi, filsafat dan masih banyak lagi. Bahkan menurut www.time.com, beberapa program podcast dapat menyamai popularitas serial drama televisi.

Belakangan, podcast juga mengacu pada materi dalam bentuk video. Sehingga pengertian podcast dapat mengacu pada podcast audio atau podcast video. Apple sendiri membuat batasan podcast sebagai siaran audio dan video yang tersedia di internet untuk diputarkan pada perangkat portable atau komputer, seperti iPad, Ipod, atau Mac. Singkat cerita, istilah podcast diartikan sebagai materi audio atau video yang tersedia di internet yang dapat secara otomatis dipindahkan ke komputer atau media. (Efi fadilah, 2017)

\subsubsection{Multimedia}

Multimedia menurut etimologinya berasal dari kata multi yang berarti banyak dan dari kata media yang berarti sarana komunikasi untuk memberikan informasi. Multimedia juga merupakan suatu sistem yang terdiri dari perangkat keras, perangkat lunak dan alat-alat lain seperti : televisi, monitor, video, dan system piringan optik yang dimaksudkan untuk menghasilkan penyajian audio visual penuh. Multimedia mempunyai peranan yang sangat penting karena saat ini multimedia dijadikan salah satu alat untuk bersaing di era globalisasi ini. Di samping itu pada abad 21 ini multimedia akan menjadi ketrampilan dasar yang sama pentingnya dengan ketrampilan membaca [4].

\subsubsection{Prosedur Pemrograman KRS}

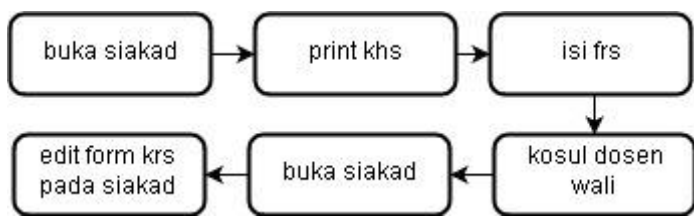

Gambar 1 Diagram pemrograman krs.

Prosedur pemrograman krs dimulai dengan membuka siakad dan print dpa, lalu mengevaluasi nilai dari khs tersebut. Pergi ke recording dan meminta form Encana studi lalu mengisi form tersebut. Setelah itu konsultasi frs tersebut ke dosen wali, jika dosen wali setuju program krs di siakad.

\subsubsection{Prosedur Pemrograman Batal Tambah}

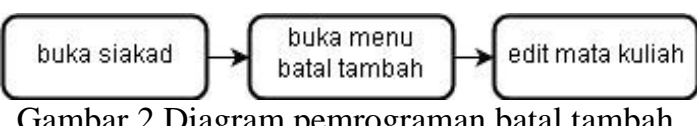

Prosedur pemrograman batal tambah dimulai dengan membuka siakad dan masuk ke menu batal tambal, setelah mengedit mata kuliah yang sudah deprogram saat krs, lalu pilih simpan.

\subsubsection{Prosedur Praktikum}

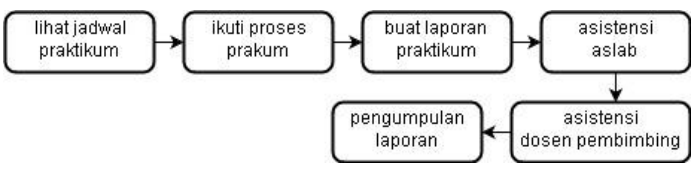

Gambar 3 Diagram prosedur praktikum.

Prosedur praktikum dimulai dengan melihat jadal praktikum yang tertera di lab informatika, lalu mengikuti proses praktikum. setelah itu menyusun laporan dengan bimbingan asisten lab. Setelah bimbingan asisten lab, lalu bimbingan dosen pembimbing, jika sudah bimbingan dosen pebimbing kumpulkan laporan praktikum tersebut ke recording. 


\subsubsection{Prosedur PKN}

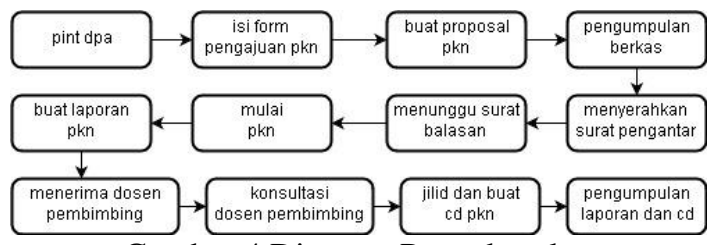

Gambar 4 Diagram Prosedur pkn.

Prosedur pkn dimulai dengan print dpa, lalu meminta dan mengisi form pengajuan pkn, dan membuat proposal pkn. Setelah itu kumpulkan ke tiga berkas tersebut ke recording. Lalu pihak recording akan memberikan surat pengantar yang akan diberikan ke tempat pkn, lalu akan menerima surat balasan dari tempat pkn. Setelah itu mulai pkn dan susun laporan pkn berdasarkan apa yang dikerjakan saat pkn. Setelah mendapatkan dosen pembimbing, bimbingan laporan pkn tersebut. Setelah bimbingan selesai, maka jilid laporan pkn dan buat cd pkn yang akan dikumpulkan ke perpustakaan di kampus 2 .

\subsubsection{Prosedur Skripsi}

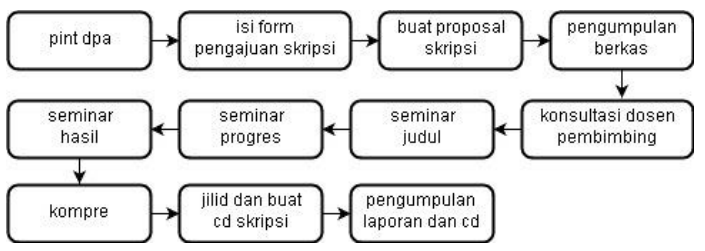

Gambar 5 Diagram Prosedur skripsi.

Prosedur pkn dimulai dengan print dpa, lalu meminta dan mengisi form pengajuan skripsi, dan membuat proposal skripsi. Setelah itu kumpulkan ke tiga berkas tersebut ke recording. Lalu recording akan memberikan dosen pembimbing proposal pkn. setelah bimbingan proposal pkn, akan ada seminar proposal. Setelah seminar proposal, recording akan memberikan dosen pembimbing 1 dan 2. Stelah bimbingan kepada kedua dosen tersebut, proposal progres. Setelah itu lanjut ke seminar hasil, jika lulus seminar hasil maka akan lanjut ke kompre. Setelah lulus kompre jilid laporan yang sudah direvisi dan buat cd skripsi yang akan dikumpulkan ke perpustakaan di kampus 2.

\section{2..2.8 Prosedur Pembayaran SPP}

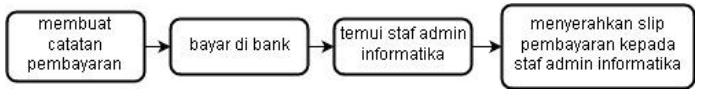

Gambar 6 Diagram pembayaran spp.

Prosedur pembayaran spp dimulai dengan membuat catatan lalu membayar di bank, lalu temui staff administrasi informatika dan menyerahkan bukti pembayaran untuk proses validasi pembayaran.

\subsubsection{Prosedur Pengajuan Cuti}

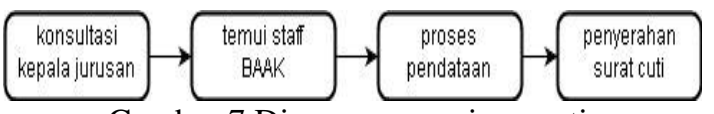

Gambar 7 Diagram pengajuan cuti.

Prosedur pengajuan cuti dimulai dengan konsultasi dan meminta surat pengantar cuti kepada kepala jurusan teknik informatika. seteah itu temui staff BAAK yang berada di kampus 1, dan serahkan surat pengantar tersebut. Staff BAAK akan mendata dan memberikan surat ijin cuti. Setelah itu menyerahkan surat ijin cuti tersebut kepada beberapa pihak.

\subsubsection{Prosedur Pendaftaran Anggota Asisten Lab}

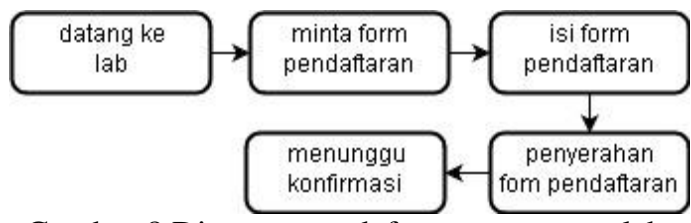

Gambar 8 Diagram pendaftaran anggota aslab.

Prosedur pendaftaran anggota asisten lab dimulai dengan meminta dan mengisi form pendaftaran kepada asisten lab, lalu tes kemampuan dan tes mengajar. Setelah itu penerimaan akan di umumkan melewati kontak yang dicantumkan di form pendaftaran.

\subsubsection{Prosedur Pendaftaran Anggota Himpunan}

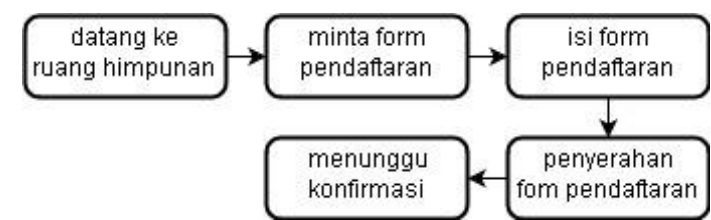

Gambar 9 Diagram Pendaftaran anggota himpunan.

Prosedur pendaftaran anggota asisten himpunan dimulai dengan meminta dan mengisi form pendaftaran kepada anggota himpunan. lalu anggota himpunan akan memulai wawancara. Setelah itu penerimaan akan di umumkan melewati kontak yang dicantumkan di form pendaftaran.

\section{METODE PENELITIAN}

\subsection{Diagram Blok}

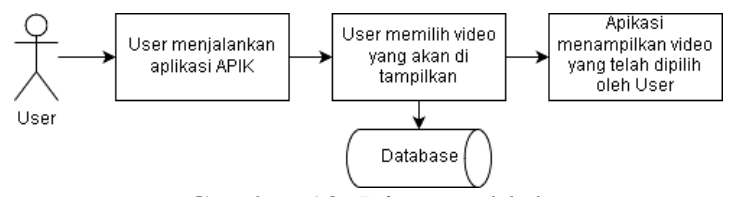

Gambar 10. Diagram blok 
Penjelasan dalam diagram blok tersebut adalah awal langkah user menjalankan aplikasi, lalu memilih video yang akan ditampilkan. Setelah itu user aplikasi akan menampilkan video yang telah dipilih oleh user.

\subsection{Use case}

Berikut ini merupakan gambar use case pada aplikasi pendukung akademik.

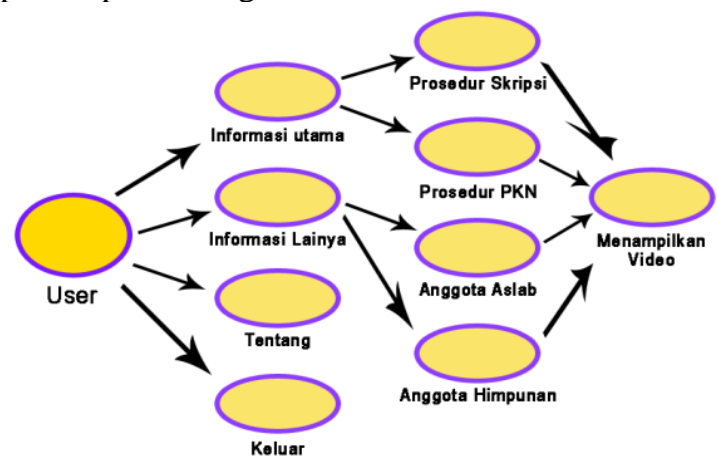

Gambar 11. Usecase
Dalam hal ini actor adalah user yang akan menggunakan aplikasi. User dapat memilih beberapa menu yang tersedia di aplikasi yaitu menu informasi utama, informasi lainya, tentang, dan keluar. Dalam menu informasi utama dan informasi lainya terdapat sub menu yang menunjukan judul video podcast, yang nantinya akan menampilkan video podcast itu sendiri.

\subsection{Flowchart}

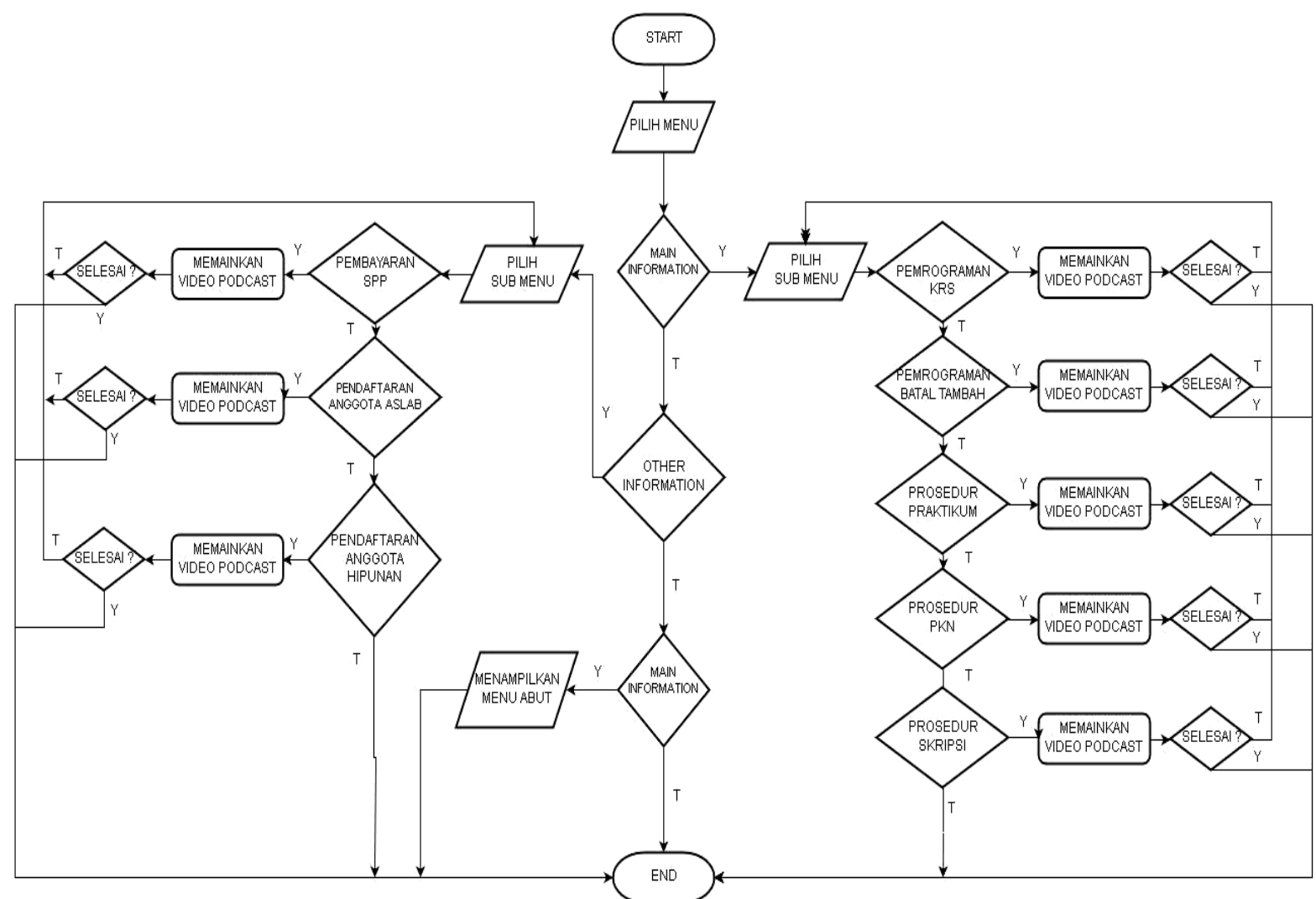

Dari flowchart program di atas dapat dijelaskan bahwa pada menu awal user dapat memilih tiga menu yaitu main information, other menu, dan menu about. Didalam menu main information dan other information terdapat pilihan informasi, jika user memilih sebuah informasi maka akan membuka menu pemutaran video setelah itu aplikasi akan memainkan video yang telah dipilih. Jika user memilih menu about, maka aplikasi akan menampilkan isi dari menu about tersebut.

\section{HASIL DAN PEMBAHASAN \\ 4.1 Implementasi Sistem \\ 4.1.1 Tampilan Menu Utama}

Pada menu utama menampilkan pilihan sub menu, yaitu Informasi utama, Informasi lainya dan 
tentang yang mempunyai fungsi masing-masing. Sebagai mana di tunjukan pada Gambar di bawah.

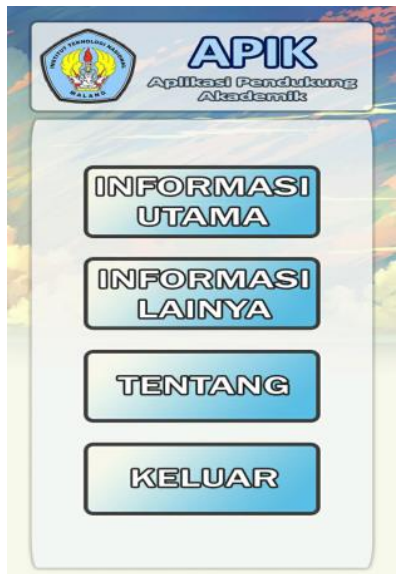

Gambar 12. Tampilan main menu

\subsubsection{Tampilan Informasi Utama}

Pada menu ini terdapat beberapa sub menu yang akan menampilkan informasi utama berupa video podcast yang sesuai dengan nama sub menu tersebut.

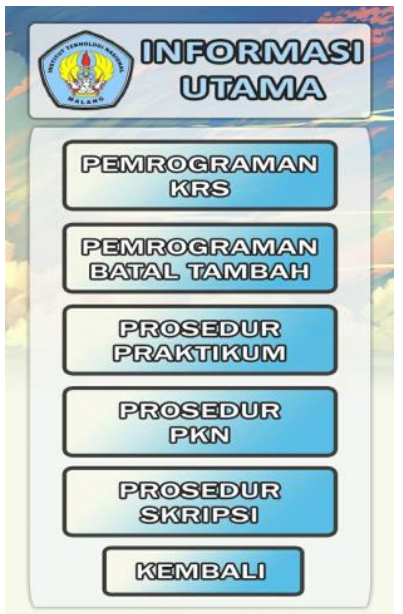

Gambar 13. Tampilan informasi utama

\subsubsection{Tampilan Informasi Lainya}

Pada menu ini terdapat beberapa sub menu yang akan menampilkan informasi tambahan berupa video podcast yang sesuai dengan nama sub menu tersebut.

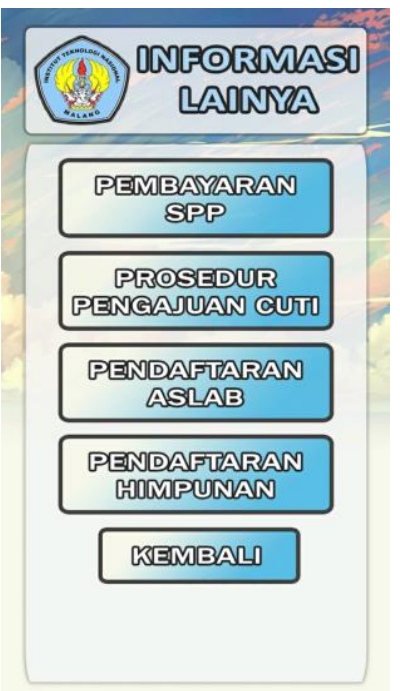

Gambar 14. Tampilan informasi lainya

\subsubsection{Tampilan Pemutar Video Podcast}

Pada halaman ini terdapat pemutar video yang telah diberi beberapa tombol yang bertujuan untuk mengontrol video yang sedang di putar.

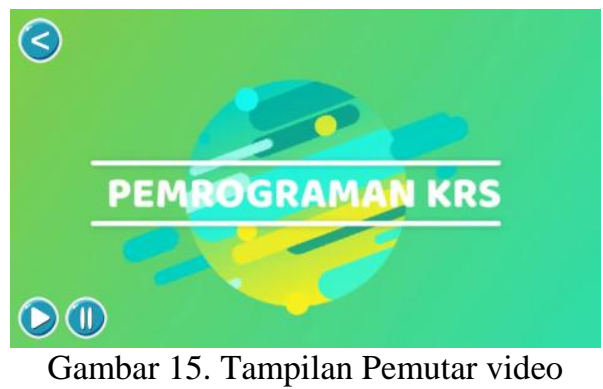

\subsection{Pengujian Fungsional}

Tabel 1 Pengujian fungsional

\begin{tabular}{clll}
\hline NO & \multicolumn{1}{c}{ Skenario } & \multicolumn{1}{c}{ Hasil Yang Diharapkan } & Hasil Pengujian \\
\hline $\mathbf{1}$ & $\begin{array}{l}\text { Menjalankan aplikasi yang telah } \\
\text { terpasang }\end{array}$ & $\begin{array}{l}\text { Aplikasi berkerja dan berjalan } \\
\text { dengan baik }\end{array}$ & Sesuai harapan \\
\hline $\mathbf{2}$ & Memilih menu pada aplikasi & $\begin{array}{l}\text { Berpindah ke halaman yang } \\
\text { sesuai dengan pilihan }\end{array}$ & Sesuai harapan \\
\hline $\mathbf{3}$ & $\begin{array}{l}\text { Menjalankan tombol kontrol } \\
\text { pada pemutar video }\end{array}$ & $\begin{array}{l}\text { Dapat berfungsi dengan baik } \\
\text { seperti play dan pause }\end{array}$ & Sesuai harapan \\
\hline $\mathbf{4}$ & $\begin{array}{l}\text { Memutar video Pemrograman } \\
\text { KRS (indonesia) }\end{array}$ & $\begin{array}{l}\text { menampilkan video dan } \\
\text { mengeluarkan suara dari video } \\
\text { yang dipilih. }\end{array}$ & Sesuai harapan \\
\hline $\mathbf{5}$ & Memutar video Pemrograman & $\begin{array}{l}\text { menamilkan video dan } \\
\text { Kengeluarkan suara dari video } \\
\text { Kang dipilih. }\end{array}$ & Sesuai harapan
\end{tabular}




\begin{tabular}{|c|c|c|c|}
\hline NO & Skenario & Hasil Yang Diharapkan & Hasil Pengujian \\
\hline 6 & $\begin{array}{l}\text { Memutar video Pemrograman } \\
\text { Batal Tambah (indonesia) }\end{array}$ & $\begin{array}{l}\text { menampilkan } \quad \text { video } \\
\text { mengeluarkan } \\
\text { yang dipilih. }\end{array}$ & Sesuai harapan \\
\hline 7 & $\begin{array}{l}\text { Memutar video Pemrograman } \\
\text { Batal Tambah (inggris) }\end{array}$ & $\begin{array}{l}\text { menampilkan } \quad \text { video } \\
\text { mengeluarkan } \\
\text { yang dipilih. }\end{array}$ & Sesuai harapan \\
\hline 8 & $\begin{array}{l}\text { Memutar video Prosedur } \\
\text { Praktikum (indonesia) }\end{array}$ & $\begin{array}{l}\text { menampilkan } \quad \text { video } \\
\text { mengeluarkan } \\
\text { yang dipilih. }\end{array}$ & Sesuai harapan \\
\hline 9 & $\begin{array}{l}\text { Memutar video Prosedur } \\
\text { Praktikum (inggris) }\end{array}$ & 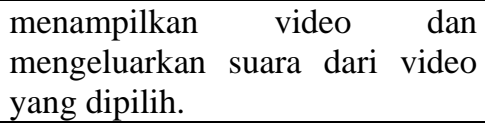 & Sesuai harapan \\
\hline 10 & $\begin{array}{l}\text { Memutar video Prosedur Skripsi } \\
\text { (indonesia) }\end{array}$ & $\begin{array}{l}\text { menampilkan } \begin{array}{l}\text { video } \\
\text { mengeluarkan } \\
\text { yang dipilih. }\end{array} \\
\text { suara dari } \\
\text { video }\end{array}$ & Sesuai harapan \\
\hline 11 & $\begin{array}{l}\text { Memutar video Prosedur Skripsi } \\
\text { (inggris) }\end{array}$ & $\begin{array}{l}\text { menampilkan } \quad \text { video } \\
\text { mengeluarkan } \\
\text { yang dipilih. }\end{array}$ & Sesuai harapan \\
\hline 12 & $\begin{array}{l}\text { Memutar video Prosedur PKN } \\
\text { (indonesia) }\end{array}$ & $\begin{array}{l}\text { menampilkan } \quad \text { video dan } \\
\text { mengeluarkan } \\
\text { yang dipilih. }\end{array}$ & Sesuai harapan \\
\hline 13 & $\begin{array}{l}\text { Memutar video Prosedur PKN } \\
\text { (indonesia) }\end{array}$ & $\begin{array}{l}\text { menampilkan } \quad \text { video } \\
\text { mengeluarkan } \\
\text { yang dipilih. }\end{array}$ & Sesuai harapan \\
\hline 14 & $\begin{array}{l}\text { Memutar video Pembayaran SPP } \\
\text { (indonesia) }\end{array}$ & 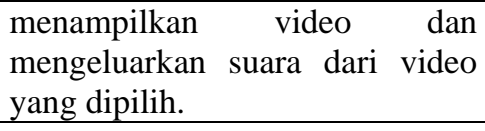 & Sesuai harapan \\
\hline 15 & $\begin{array}{l}\text { Memutar video Pembayaran SPP } \\
\text { (inggris) }\end{array}$ & $\begin{array}{l}\text { menampilkan } \quad \text { video } \\
\text { mengeluarkan } \\
\text { yang dipilih. }\end{array}$ & Sesuai harapan \\
\hline 16 & $\begin{array}{l}\text { Memutar video Pengajuan Cuti } \\
\text { (indonesia) }\end{array}$ & $\begin{array}{l}\text { menampilkan } \quad \text { video } \\
\text { mengeluarkan } \\
\text { yang dipilih. }\end{array}$ & Sesuai harapan \\
\hline 17 & $\begin{array}{l}\text { Memutar video Pengajuan Cuti } \\
\text { (inggris) }\end{array}$ & $\begin{array}{l}\text { menampilkan } \quad \text { video dan } \\
\text { mengeluarkan } \\
\text { yang dipilih. }\end{array}$ & Sesuai harapan \\
\hline 18 & $\begin{array}{l}\text { Memutar video Pendaftaran } \\
\text { Aslab (indonesia) }\end{array}$ & $\begin{array}{l}\text { menampilkan } \begin{array}{l}\text { video dan } \\
\text { mengeluarkan } \\
\text { yang dipilih. }\end{array} \\
\text { yara dari video } \\
\end{array}$ & Sesuai harapan \\
\hline 19 & $\begin{array}{l}\text { Memutar video Pendaftaran } \\
\text { Aslab (inggris) }\end{array}$ & $\begin{array}{l}\text { menampilkan } \quad \text { video } \\
\text { mengeluarkan } \\
\text { yang dipilih. }\end{array}$ & Sesuai harapan \\
\hline 20 & $\begin{array}{l}\text { Memutar video Pendaftaran } \\
\text { Himpunan (indonesia) }\end{array}$ & $\begin{array}{l}\text { menampilkan } \quad \text { video dan } \\
\text { mengeluarkan } \\
\text { yang dipilih. }\end{array}$ & Sesuai harapan \\
\hline 21 & $\begin{array}{l}\text { Memutar video Pendaftaran } \\
\text { Himpunan (inggris) }\end{array}$ & $\begin{array}{l}\text { menampilkan } \quad \text { video } \\
\text { mengeluarkan } \\
\text { yang dipilih. }\end{array}$ & Sesuai harapan \\
\hline
\end{tabular}

Pada tahap pengujian alpha yang di lakukan pengembang menunjukkan bahwa semua fungsi $100 \%$ valid sesuai yang diharapkan. 


\subsection{Pengujian Kompatibilitas}

Pengujian kompatibilitas dilakukan untuk menguji apakah aplikasi dapat berjalan dengan baik pada versi android yang berbeda. Pada Tabel berikut ini adalah hasil dari pengujian aplikasi pada versi android yang berbeda.

Tabel 2 Pengujian Kompabiitas

\begin{tabular}{|c|c|c|}
\hline NO & Sistem Operasi & Keterangan \\
\hline 1 & $\begin{array}{c}\text { Android } \\
\text { Lollipop (5.1) }\end{array}$ & $\begin{array}{c}\text { Aplikasi berjalan } \\
\text { lambat saat } \\
\text { memainkan video }\end{array}$ \\
\hline 2 & $\begin{array}{c}\text { Android } \\
\text { Marshmallow } \\
(6.0)\end{array}$ & $\begin{array}{c}\text { Aplikasi berjalan } \\
\text { dengan lancar }\end{array}$ \\
\hline 3 & $\begin{array}{c}\text { Android } \\
\text { Nougat (7.0) }\end{array}$ & $\begin{array}{c}\text { Aplikasi berjalan } \\
\text { dengan lancar }\end{array}$ \\
\hline 4 & $\begin{array}{c}\text { Android } \\
\text { Oreo (8.0) }\end{array}$ & $\begin{array}{c}\text { Aplikasi berjalan } \\
\text { dengan lancar }\end{array}$ \\
\hline 5 & $\begin{array}{c}\text { Android } \\
\text { Pie (9.0) }\end{array}$ & $\begin{array}{c}\text { Aplikasi berjalan } \\
\text { dengan lancar }\end{array}$ \\
\hline
\end{tabular}

Pada tahap pengujian kompabilitas diatas aplikasi dapat berjalan lancar pada Android versi Marshmallow (6.0), Nougat (7.0), Oreo (8.0), dan Pie (9.0), sedangkan pada Android versi Lollipop (5.1) berjalan lambat pada saat memainkan video didalam aplikasi.

\section{KESIMPULAN DAN SARAN}

\subsection{Kesimpulan}

Kesimpulan yang dapat diambil dari penelitian ini, sebagai berikut :

1. Aplikasi ini dapat memberikan informasi akademik teknik informatika ITN Malang dengan baik, Menurut pengujian dari 10 koresponden yang memberikan 7 penilaian baik dan 3 penilaian sangat baik.

2. Menurut pengujian kombatibilitas aplikasi ini dapat berjalan secara lancar pada Android versi $6,7,8,9$, dan berjalan secara lambat pada Android versi 5 .

\subsection{Saran}

Dari beberapa simpulan yang telah diambil, maka dapat dikemukakan saran yang akan membantu untuk pengembangan, yaitu dapat dikembangkan untuk platform mobile lainya seperti ios atau windows phone.

\section{DAFTAR PUSTAKA}

[1] Adinda dan Adjie. (2001). Film Animasi 2D Berbasis 3D Menggunakan Teknik Cell Shading Berjudul The Postman Story. STIKOM: Surabaya.

[2] B. Uno, Hamzah \& Lamatenggo, Nina. (2011). Teknologi Komunikasi dan Informasi dalam Pembelajaran. Jakarta: PT. Bumi Aksara.

[3] Chris Evans. (2007). The effectiveness of mlearning in the form of podcast revision lectures in higher education

[4] Efi Fadilah, Pandan Yudhapramesti, Nindi Aristi. (2017). Podcast sebagai Alternatif Distribusi Konten Audio.

[5] Panji Novantara, M.T. (2016). RANCANG BANGUN APLIKASI PANDUAN AKADEMIK SEBAGAI MEDIA INFORMASI DAN PEDOMAN PERKULIAHAN BAGI CALON MAHASISWA BARU DI UNIVERSITAS KUNINGAN BERBASIS ADOBE FLASH CS3.

[6] Pardani Panggara Putri, Nila Feby Puspitasari, S.Kom. M.Cs. (2016). BUKU PANDUAN AKADEMIK DIGITAL BERBASIS ANDROID PADA STMIK AMIKOM YOGYAKARTA.

[7] Silabus Teknik Informatika ITN Malang. (20152019).

[8] Sulihati dan Andriyani. (2016). Aplikasi Akademik Online Berbasis Mobile Android

[9] T. BELL, A. COCKBURN, A.WINGKVIST \& R. GREEN. (2007) . Podcasts as a supplement in tertiary education: an experiment with two Computer Science courses. 